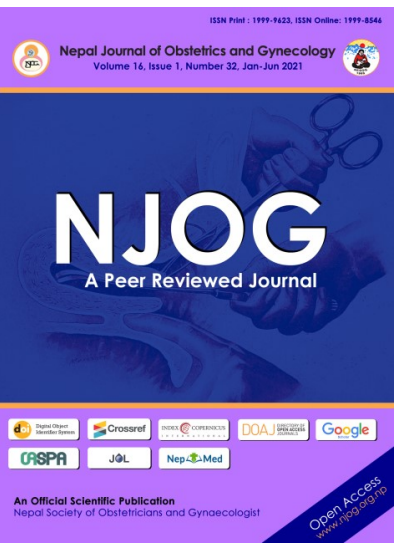

CORRESPONDENCE

Dr Monica Gurung

Department of Obstetrics and Gynaecology

$\mathrm{B}$ and $\mathrm{C}$ Medical College

Teaching Hospital,

Birtamode, Jhapa, Nepal

Email:monicagurung717@ gmail.com;

Phone: +977-9849365619

Received: November 15 , 2020

Accepted: April 1, 2021

\section{Citation:}

Gurung M, Baral G. Recurrent Puerperal Uterine Inversion. Nep J Obstet Gynecol. 2021;16(32):137 -138. DOI: https:// doi.org/10.3126/ njog.v16i1.37626

\title{
Recurrent Puerperal Uterine Inversion
}

\author{
Monica Gurung, Gehanath Baral
}

Department of OBGYN, Paropakar Maternity and Women's Hospital, Kathmandu

\section{ABSTRACT}

Uterine inversion is rare and life threatening obstetric complication. This is a case of recurrent uterine inversion managed successfully with Johnson's Maneuver followed by condom tamponade placement.

Keywords: intrauterine condom catheter, Johnson's maneuver, recurrent uterine inversion

\section{INTRODUCTION}

Uterine inversion is called when the uterus is turned inside-out partially or completely. The incidence of uterine inversion varies from one in 2,00020,000 deliveries. ${ }^{1}$ Uterine inversion can be puerperal or non puerperal. Degree of inversion varies according to the severity of inversion, delay between delivery and diagnosis of inversion. The risk factors for uterine inversion is fundal attachment of placenta, fundal leiomyoma, control cord traction before signs of placental separation or in atonic uterus and abnormally morbidly adherent placenta associated with Placenta Accreta Syndrome. The complications are postpartum hemorrhage and shock due to hypovolemia and neurogenic.

\section{CASE}

A 30 years old $\mathrm{P} 2$ with preterm vaginal delivery at 36 weeks of gestation referred-in after 2.5 hours of delivery at 7:30am on 25 January 2018. She had $2.4 \mathrm{~kg}$ normal birth. She was anemic and abdomen was normal with no uterus palpable. There was a smooth globular hyperemic mass at introitus with active bleeding present and it was continuous with cervix and vagina. [Figure $-1]$

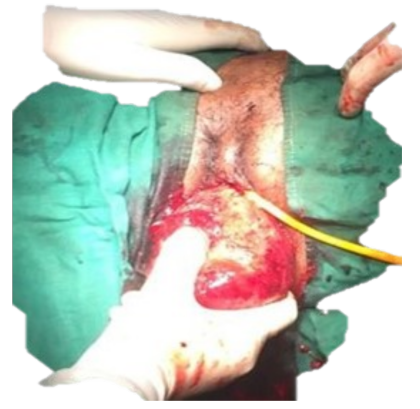

Figure-1: Complete uterine inversion
The diagnosis made was "Acute Complete Uterine Inversion with PPH"; Folley catherization was done. Her hemoglobin was7.4 gm/ $\mathrm{dl}$, platelets count $213,000 / \mathrm{mm}^{3}$ and PT $14 \mathrm{sec}$. She was transferred to Operation Theater and Johnson's Maneuver (the uterus is replaced by pushing on the inverted fundus with palm of hand and fingers in direction of long axis of the vagina through the cervical ring with pressure directed toward the umbilicus) applied under general anesthesia (GA). Oxytocin infusion started and prophylactic intrauterine Condom Tamponed kept. Patient was transferred to intensive care unit (ICU). Two units of blood transfused. After $28 \mathrm{hrs}$ of procedure, Condom Tamponade was slowly removed and Folley catheter also removed. Uterus was 20 weeks size and well contracted; cervical os was parous and lochia rubra was present. $\mathrm{Pa}-$ tient was transferred to ward after 2 hrs of removal of condom catheter. During voiding urine after $9 \mathrm{hrs}$ of removal of condom tamponade, she noticed sudden bulge of mass coming out per vagina. Abdomen was soft non tender and uterus was not palpable but there was a soft non tender hyperemic mass at the introitus. Repeat uterine inversion was identified; Foley catheter drained $450 \mathrm{ml}$ of urine. Again she had Johnson's Maneuver under GA followed by prophylactic condom poned placement. Oxytocin infusion 
continued for $12 \mathrm{hrs;}$ two units of blood transfused; and Folley catheter removed after 72 hours. She was discharged on $5^{\text {th }}$ day of admission; uterus well contracted at 18 weeks size and normal contour, and no vaginal bleeding. On ultrasonography there was normal contour of uterus and residual urine of 50 $\mathrm{ml}$. Follow-up visit after one and six weeks was normal.

\section{COMMENTS}

The incidence of uterine inversion in Paropakar Maternity and Women's Hospital in 2017 was 1/18993 deliveries. The incidence is almost constant over three years from 2006 to 2009 with four reported cases from 56,455 deliveries. $^{2}$ This recurrent uterine inversion is the first known and reported case in our institute. There is no clear guideline on the management of recurrent uterine inversion. There are very few case reports on recurrent uterine inversion and different methods of management. In 2009, Soleymani MH et al have reported first successful management of recurrent uterine inversion with Surgical Obstetric Silicone bakri balloon; then by Elósegui JJH et al in 2011.,4 Kabir N et al and Sharma $\mathrm{N}$ et al have reported acute uterine inversion managed by Johnson's maneuver; then subacute uterine inversion by Haultain's operation (cervical ring is posteriorly incised to facilitate uterine replacement by Huntington method). ${ }^{5,6}$ Another case report of successful management of recurrent puerperal uterine inversion was managed first by Jhonson's maneuver for acute inversion and for recurrent uterine inversion exploratory laparotomy was done to reposit by Huntington technique (progressive upward traction on each round ligament by application of atraumatic clamps with simultaneous upward pressure transvaginally) and multiple Cho suture; bilateral uterine arteries and utero ovarian arteries were ligated prophylactically. Vaginal pack with roller gauze kept prophylactically to prevent reinversion.

Recent advances in the management of uterine inversion involves case reports on being managed by laparotomy followed by use of obstetric ventose and in non puerperal case being managed laproscopically. 8,9

The cause of this uterine inversion could be uterine atony that could have precipitated by urinary retention like in the case reported by Kabir $\mathrm{N}$ et al. But Urinary retention could be both precipitating factor as well as the obstructive complication of uterine inversion.

\section{CONCLUSIONS}

Recurrent uterine inversion can be managed conservatively with Johnson's maneuver and intrauterine condom tamponade placement. Urinary retention should always be kept in mind.

\section{ACKNOWLEDGEMENT}

I acknowledge Meena Jha, Devi Gurung and Sujita Shrestha for their contribution during emergency case management.

\section{REFERENCES}

1. Cunningham FG, Leveno KJ, Bloom SL, Spoong CY, Dashe JS, Hoffman B, et al. Williams Obstetrics. $24^{\text {th }}$ Ed, Mc Graw Hill Education. 2014. Chapter 41, Obstetrical Hemorrhage. P 787-8

2. Upadhyaya I, Chaudhary P. Acute Uterine Inversion: Case Series from Paropakar Maternity and Women's Hospital. Nep J Obstet Gynecol. 2013;8(1):46-9.

3. Soleymani Majd H, Pilsniak A, Reginald P. Recurrent uterine inversion: a novel treatment approach using SOS Bakri balloon. BJOG. 2009;116:999-1001.

4. Elósegui JJH, Arenas FJF, García AC, López JAL, Peinado GC, Martí JMT. Conservative management of a recurrent puerperal uterine inversion with bakri balloon tamponade. Open J Obstet Gynecol. 2011; 1: $197-$ 201. URL: https://www.jstage.jst.go.jp/article/ jsshp/2/1/2_1/_html/-char/en

5. Kabir N, Islam F, Zannat F, Razzak M. Bangladesh J Obstet Gynaecol. 2008;23(1):35-7.

6. Sharma N, Ram K, Sharma A, Sharma S. A unique case of recurrent uterine inversion requiring double reposition. Int J Reprod Contracept Obstet Gynecol. 2013;2(3):427-9. DOI: 10.5455/2320-1770.ijrcog20130935

7. Nambisan B. Successful management of recurrent puerperal uterine inversion. Int $\mathrm{J}$ Reprod Contracept Obstet Gynecol. 2016;5(10):361921. DOI: http://dx.doi.org/10.18203/23201770.ijrcog20163458

8. Antonelli E, Irion O, Tolck, Morales M. Subacute uterine inversion: description of a novel replacement technique using obstetric ventose. BJOG. 2006;113:846-7.

9. Auber M, Darwish B, Lefebure A, Ness J, Roman $\mathrm{H}$. Management of nonpuerperal uterine inversion using a combined laparoscopic and vaginal approach. Am J Obstet Gynecol. 2011;204 (6):e7-e9. 